\title{
Assessing The Effect Of International Relations On Tourism Demand In The Context Of Turkey-Russia Aircraft Crisis
}

\author{
Abdullah USLU \\ Manavgat Faculty of Tourism, Akdeniz University, Turkey \\ Bayram AKAY \\ School of Tourism and Hotel Management, Burdur Mehmet Akif Ersoy University, \\ Turkey
}

Received: 21 February 2019. Revision received: 28 May 2019. Accepted: 29 May 2019

\begin{abstract}
The purpose of this research is to evaluate the effect of international relations on tourism demand in the context of aircraft crisis between Turkey and Russia that occurred on November 24, 2015. The content analysis have been made through the statistics, reports and qualitative research methods of 2014-2018 published by Turkish Statistical Institute (TUIK), Association of Turkish Travel Agencies of the Ministry of Culture and Tourism (TURSAB) and Turkish Hoteliers Federation (TUROB). It has been determined in the research that the Russian tourist count and tourism revenue during the crisis $(2016=866.256$ tourists, $76.26 \%$ decrease compared to 2015) remained significantly below the tourist count and tourism revenue in the years before the crisis $(2014=4.479 .049$ tourists and $\$ 3.471 .263$ tourism revenue $-2015=$ 3.649.003 tourists and $\$ 2.609 .037$ tourism revenue). In the aftermath of the crisis, the number of Russian tourists and the revenue obtained $(2017=4.715 .438$ tourists and $\$ 2.159 .671$ tourism revenue $-2018=5.964 .613$ tourists and $\$ 3.483 .334$ tourism income) exceeded the figures before the crisis. As happened so far, the crises will also negatively affect the tourism demand in the future. The international relations have significant role in the resolution of political crises. The dependency of Turkey on European and Russian markets has deepened the crisis. Therefore, the countries should direct to alternative markets that will decrease the dependency. Turkey should grow and diversify its target markets from EU and Russia towards Middle East countries, China, India and Asia Pacific countries. Results may be achieved in fixing the international relations with all tourism shareholders acting together. Government officials (President, Prime Minister, Minister of Foreign Affairs) may normalize the relations with diplomatic solutions and discussions while other tourism shareholders (Ministry of Culture and Tourism, TURSAB, Hoteliers, travel agencies, transportation companies etc.) may do this by attending festivals, tourism forums, workshop activities in such countries and conducting public relations activities towards potential tourists.
\end{abstract}

Key words: International relations, tourism demand, crisis, Turkish-Russian aircraft crisis

JEL Classifications: Z30, G28, H12 


\section{Introduction}

The relations between Turkey and the Russian Federation is based on a deeprooted heritage (Can et al., 2018: 14). Political, economic and social relations between the two countries have shown continuous development especially during the 2000s (Erşen, 2016: 153). The fact that Turkey shot down the SU-24 type Russian, which violated the air space, near the Syrian border on November 24, 2015 caused a crisis between Turkey and Russia (İmambeyli, 2015: 1; Can et al., 2018:14).

The political crisis that occurred between the two states has significantly damaged the tourism sector (Seçilmiş et al., 2017: 498). Even the rumors of the crisis in the tourism sector, which is very sensitive to any crisis, cause the cancellation of reservations (Albeni \& Ongun, 2005: 97). In recent years, global crises such as natural disasters, internal conflicts, epidemics, technological failures, terrorist attacks, biosecurity threats, economic, political and political instability, attacks on September 11 and the Gulf War have affected the tourism demand negatively (Köşker, 2017: 217).

The tourism sector, which developed with the industrial revolution, has played an important role in the development of the country's economies since the 1950s and has been one of the three most important sectors since the 2000s. According to the data of World Tourism Organization (UNWTO), in 2017, the number of tourists traveling around the world will be 1.326.000.000 and tourism revenue will be $\$ 1.340 .000 .000$ and these figures will reach 1.602.000.000 in terms of tourist count and 2 trillion dollars in terms of revenue. These figures indicate that the tourism sector has become an important economic power for tourist-attracting countries. Macroeconomic indicators exhibit that tourism constitutes $11.7 \%$ of GDP in the world and is the largest sector providing one of the twelve jobs in the world (Alvarez et al., 2007: 453). Tourism still represents one of the largest economic sectors and is widely recognized as an important factor for country development (Lustick \& Kincl, 2012) and it is an important part of the country national economy (Gajdošik et al.,2015). However, in the tourism sector, crises cause great losses due to uncontrollable natural disasters, political disagreements, socio-economic changes, terrorism and conflict, wrong policies or management mistakes (Aymankuy, 2001: 105). In such cases, it can be said that at least a certain proportion of the international tourism movements have shifted from the regions with the crisis to safer areas; whereby the countries experiencing the crisis have lost some of their tourism income to other countries (Yeşiltaş et al., 2008: 182).

Although there are many studies that assess the effects of crises on tourism demand, no studies were encountered that examines the effects of international relations in crises on tourism demand in the literature scan made regarding the crisis in the tourism sector. The purpose of this study is to assess the effect of international relations on tourism demand by years in the context of the aircraft crisis between Turkey and Russia occurred on November 24, 2015. The study will first discuss the international relations and tourism, tourism demand, crisis in tourism and its management, the factors that cause the crisis and the aircraft crisis between Turkey and Russia. Then, the aim and question of the research, findings and suggestions will be included.

\section{Literature Review}

\subsection{International Relations and Tourism}


International relations as a concept is started to be used as inclusive of all political, social, touristic, cultural, economic, sportive, religious relations not only between states but also governments, societies, international organizations, nongovernment organizations and non-state institutions that go beyond countries (Aydemir \& Bal, 2018: 73).

International relations and tourism mesh across areas (political, economic and socio-cultural), issues (intercultural understanding, travel security, democracy development and environmental protection) and stakeholders (tourists, destinations, hosts, employees, businesses, governments, countries in different stages of development, non-governmental organizations and multinational companies). Stakeholders can be private, public or business groups (travelers, organizations or corporations). Their relationships develop in the context of globalization, borders and their possible contributions to world peace (Konrad, 2017).

Tourism is not just a matter of national growth, but must be conceptualized as part of international relations. Due to its increasingly international nature, tourism is inseparable from the field of international relations. Therefore, researches on political sciences and international relations must be added to the researches of tourism economy, geography and sociology (Clancy, 2011).

The activities of tour operators and airline companies in particular among the tourism actors internationally operating in tourism. Political and economics upheavals in one part of the world may affect travel to and from other parts, altering tourism flows and producing a knock-on economic effect. Governments can impose tourism "sanctions" that are every bit as effective as commodity embargoes. Some countries have used tourism to help solve balance of trade surpluses, to project a particular image or to promote their own ideology. Establishing and operating a tourism industry can be seen as an example of means of developing the modernization and improvement or of structural dependency or neo-colonization (Frances, 2010: 11).

\subsection{Tourism Demand}

Tourism demand is "the number of people who buy or benefit from the touristic goods and services that are offered for sale at a certain price or for the benefit of tourists" (Olal1, 1981: 165). According to another definition, it is "the amount of people willing to buy tourism products and services, supported by sufficient purchasing power and leisure time" (Bahar \& Kozak, 2013: 107).

Participation in the tourism movement may consist of individual, group or mass tourists traveling to a different location. The demand for tourism consists of three components together with the people who consume. These are (Kozak et al., 2015: 63);

- "Effective demand" that goes a tourism destination and directly participates in tourism activities,

- "Potential demand" that has a desire to travel but cannot fulfill this request due to time and monetary limitations,

- "Deferred tourism demand", which can travel when stimulated but does not have sufficient knowledge about the facilities and activities provided.

Tourism demand is influenced by economic factors, social-psychological and external factors. a) Economic Factors: Income, price, transportation, exchange rate, distance, accommodation and supply capacity and promotion activities (Tunç \& Saç, 2000). b) Social-psychological factors: Fashion, pleasures and habits, rest, relaxation, leisure, gender, age, family structure, occupation, culture and education level and social value judgments (Bahar \& Kozak, 2013: 116). c) External Factors: Political and social 
environment, war, terror, natural disasters, economic growth or stagnation, epidemics, technological progress, development in the lower and upper structure, Olympic games, great events, social-cultural attractiveness are external factors (Fletcher et al., 2012: 36). In addition Loganathan et al. (2018) state that a flexible and low exchange rate promotes international tourism demand primarily in developing countries.

The majority of the factors that restrict tourism demand are due to state or political practices. These are caused by the taxation of travels, the increase or tightening of state controls and the seasonal nature of tourism. Again, a number of restrictions regarding visa applications and the short duration of stay have negative consequences for tourism demand. In addition, tourism demand is negatively affected if the tourist attraction country or destination's investments in infrastructure and superstructure are lacking. Similarly, the competitiveness of a country with low economic status will decrease with other competing tourism countries (Bahar \& Kozak, 2013: 118). Otherwise tax issues are a partial problem of platform economy regulation for the countries (Ključnikov et al, 2018)

\subsection{Crisis and Its management in tourism sector}

As in other sectors, natural disasters and catastrophes, epidemics, economic turmoil and terrorism create crises leading to a significant decrease in tourism demand in the tourism sector (Beirman, 2003). The potential impacts of tourism crises can be evaluated on the basis of the "severity", "area" and "duration" of the crises upon assessing with a focus on tourism demand. According to its severity; there are crises that are ineffective, mild, severe, very severe and that can even bring tourism visits to a complete standstill. According to geographical domains; it can be observed to be limited to a small area, or to be effective in a whole community of cities, a country or even group of countries (Pizam, 1999: 9). Crisis in tourism is "the situations where, individually or collectively the tourists, tourism industry members and destinations face with changes that may create destructive effects" (Henderson, 2007:13).

World Tourism Organization (WTO) defines crisis as "all events that occur in unexpected moments, which reduce the confidence of tourists in the destination and hinder the usual activities of tourism enterprises". Crisis management includes activities that need to be carried out within the span of the crisis, such as the identification of warning signals, the establishment of protection and prevention mechanisms, and covers a long period of time (Paksoy, 1999: 5). The Asia-Pacific Travel Association (PATA) defines the tourism crisis as "any natural or natural disaster that has the potential to affect the tourism industry" (Simone, 2007). In another definition; tourism crisis is defined as the situation that threatens the normal functioning of tourism and the conduct of tourism-related affairs (Sönmez et al., 1999: 1314).

Crisis management is the process of taking and implementing the necessary precautions to evaluate the crisis by taking the signals of crisis and evaluating the crisis with the least loss. Crisis management is a process of evaluating warning signals against possible crises before the crisis, evaluating the preparation and prevention systems and establishing preparation and prevention systems, trying to control the crisis during the crisis and minimizing the effects and ensuring the return to equilibrium (Tüz, 2002: 2).

\subsection{Factors causing crisis}

Factors leading to the crisis can be divided into environmental (external) and organizational (internal) factors. The environmental factors causing the crisis can be 
characterized as external and organizational factors as internal causes. Economic environment, legal and political environment, technological developments, natural disasters, accidents and terrorism, socio-cultural environment, competition and international environment may be included in external factors; while the management quality (Tengilimoğlu and Öztürk, 2004: 174-178) and organizational structure, lack of management, lack of adequate information systems, habits and experiences, internal blindness may be counted among internal factors (Dinçer, 1992: 322). Scope of the tourism crises is shown in Table 1.

Table 1 Scope of Tourism Crises

\begin{tabular}{|c|c|c|}
\hline Area & External & Internal \\
\hline Economic & $\begin{array}{c}\text { Recession } \\
\text { Exchange Rate Fluctuations } \\
\text { Taxes }\end{array}$ & $\begin{array}{l}\text { Increasing Costs } \\
\text { Revenue Fall } \\
\text { Inefficiency }\end{array}$ \\
\hline Political & $\begin{array}{c}\text { Government Policies } \\
\text { International relations } \\
\text { Instability } \\
\text { Terror }\end{array}$ & \\
\hline Socio-cultural & $\begin{array}{l}\text { Chaos } \\
\text { Crime }\end{array}$ & $\begin{array}{l}\text { Personnel Strength } \\
\text { Cultural Conflicts } \\
\text { Overdevelopment }\end{array}$ \\
\hline Environmental & $\begin{array}{c}\text { Natural disasters } \\
\text { (Fire, quake, flood etc.) } \\
\text { Pollution } \\
\text { Epidemics }\end{array}$ & Environmental Distortion \\
\hline Technological & $\begin{array}{c}\text { Computer System Errors } \\
\text { Mechanical Errors } \\
\text { Design Errors }\end{array}$ & Transportation Accidents \\
\hline Commercial & $\begin{array}{c}\text { Legislation } \\
\text { Government Intervention }\end{array}$ & $\begin{array}{c}\text { Competition } \\
\text { Labor Disputes } \\
\text { Management Decisions } \\
\text { Human Errors }\end{array}$ \\
\hline
\end{tabular}

Source: Henderson (2007: 6).

As observed in the table, economic, political, socio-cultural, environmental, technological and commercial internal and external causes can cause tourism crises in a regional, national and universal scale (Henderson, 2016; Davras \& Aktel, 2018). September 11 attacks in 2001, Iraq War in 2003, terrorist attacks in Madrid in 2004, Egypt and Bombay in 2005 and London in 2006, the tsunami disaster in the Asia-pacific region in 2004, the outbreak in the UK in 2001, Avian influenza epidemics in Asia in 2003-2004 are examples of tourism crises (Okumuş \& Karamustafa, 2005). Unexpected tragedies, such as airline crashes, disasters and currency instability also decreases international tourism demand (Loganathan et al., 2018).

The tourism sector in our country is also affected by a number of national and international events. Economic crises in 1994, 2000, 2001 and 2008 (Ayaz, 2016), Marmara region earthquake in 1999 and the Iraq-Kuwait War that took place between 2003 and 2011, Avian influenza in 2006 and the Syrian Civil War that has continued since 2011 can be seen as a number of events that negatively affect the tourism of our country (Davras \& Aktel, 2018).

\subsection{Aircraft Crisis between Turkey and Russia}


The "Arab Spring", which started in 2010, spread with a domino effect and started to blow an air of objection and strong opposition against governments in countries where there were serious problems about democracy and had authoritarian administrations (Demir, 2016). The first important demonstration against the regime was held in Dera on 15 March 2011 in Syria and then the events developed rapidly (Eker, 2014: 22).

While the Turkish government wanted the overthrow of the Assad regime, the Russian government, in addition to economic support, has even sent its army into Syrian territory in order to support the Assad regime. The conflicts of interest arising as a result of the exchange of moves led to the escalation of tension between Turkey and Russia (Yenişehirlioğlu et al., 2016: 77). A bomber aircraft of Russian air forces, which violated the Turkish air space and continued to do so despite all the warnings, was shot down by the jets belonging to Turkish Air Forces on November 24, 2015. After this incident, the statements of the Russian leader Putin and the Russian administration almost brought the Turkish-Russian relations to a standstill (Şahin et al., 2017: 474).

After the aircraft crisis, Russian authorities announced that they decided to impose several economic and social sanctions against Turkey. These sanctions are as follows (Yenişehirlioğlu et al., 2016: 77; Şahin et al., 2017: 474):

- Cancellation of the license of Turkish tour operators in Russia,

- Cancellation of charter flights from Russia to Turkey,

- Stopping the sale of package tours to Turkey,

- Discontinuing visa-free travel application,

- Stopping the import of some food products as of 1 January 2016,

- Cessation of the cooperation between the Russian universities and Turkey,

The first step in the process of normalization of Turkish-Russian relations was laid on June 12, 2016 by the letter of President Recep Tayyip Erdoğan to Russia's President Vladimir Putin on the Russian Unity Day. Then, two leaders met in St. Petersburg on August 9, 2016 and it was announced after the meeting that an agreement was made to bring the relations back to the pre-crisis situation (Şahin et al., 2017: 474).

Prime Minister Binali Yildırım went to Moscow on 6 December 2016 with the invitation of his Russian counterpart, Dmitry Medvedev. Y1ldirım met with the President of the Federation Council, Valentina Matviyenko, Prime Minister Medvedev and, finally, President Putin in the Kremlin. In order to deepen the economic cooperation in the contacts, the general status of bilateral relations, especially the joint projects in the fields of energy, agriculture, tourism, industry and transportation, and regional-international developments were discussed (Çulha, 2016: 227). After these meetings, Turkish-Russian relations have returned to normal in 2017. Indeed, the number of Russian tourists visiting Turkey in 2016 was 866.256 compared to 2015 and there was a $26 \%$ decline. In 2017, 4.715 .438 tourists came and an increase of $444.35 \%$ occurred compared to the previous year (Ministry of Culture and Tourism, Directorate General for Promotion, 2018: 5).

\section{Methodology}

The research is based on text/document scan from the qualitative research methods, which is defined as obtaining data by scanning all written and verbal records kept retrospectively such as books, newspapers, magazines, reports, encyclopedia and letters (Kozak, 2015: 31; Yıldırım \& Şimşek, 2008: 8). Quantitative and qualitative 
content analysis can be made on texts and documents (Altunışık et al., 2005: 260). Document analysis has been carried out in accordance with the purpose of the research through the tourism statistics of Turkey Statistical Institute (TUIK), the Ministry of Culture and Tourism, Association of Turkish Travel Agencies (TURSAB), Hotel Association of Turkey (TUROB), magazines, booklets, brochures and reports (Altunış1k et al., 2005: 65). In the research, the pre-crisis years of 2014-2015 and crisis period in 2016 and in 2017-2018, when relations returned to normal, were compared and the changes in the tourism demand have been interpreted in accordance with the international relations.

\subsection{Purpose and question of the research}

The main purpose of this research is to assess the effect of international relations on tourism demand in the context of the aircraft crisis between Turkey and Russia occurred on November 24, 2015. In line with this general purpose, the research questions to which answers are sought for are as follows;

- How did the international relations between RF-Turkey progress in the crisis period?

- Did the international relations between RF-Turkey affect the peace?

- Did the economic factors affecting the tourism demand in crisis (income, price, transportation, exchange rate, distance, accommodation, supply capacity and promotion activities) influence the Turkish tourism demand in the crisis?

- Did the socio-psychological factors (fashion, pleasures and habits, rest and relaxation, leisure time, gender, age, family structure, occupation, cultural and educational level) affect the Turkish tourism demand in the crisis?

- Did the external factor (political and social environment, war, terror, natural disasters, economic growth or stagnation, epidemics) affect the Turkish tourism demand in the crisis?

\subsection{Findings}

The international tourism demand is usually measured in terms of the number of tourists going to the country of origin (sending tourists) from the country to the destination (the country accepting tourists or the place of attraction), or measured by the expenditure of tourists from the country sending tourists to the destination country. In addition, the number of overnight stays of tourists in the destination is also used as an alternative measure. It is the export revenue for the destination country of the arrival of the tourists and the import expense for the tourist sending country (Proença \& Soukiazis, 2005).

The development of international tourism depends on the establishment of good inter-governmental political relations. Agreements in airline passenger transport, customs taxes on tourists and decisions to be taken for the determination of visas directly affect tourism activities (Matthews, 1978). Ključnikov et al. (2018) investigate the actual size of the AirBnB accommodation sector in Prague, Czech Republic to identify its specific features and evaluate the situation and the impact of short-term rentals via AirBnB on Prague accommodation market in comparison with other European cities. AirBnB is the segment of sharing economy. The countries or cities may impose a number of prohibitions on rental demand due to a low-scale potential tax evasion. The removal of visas or the reduction of legal requirements will lead to an 
increase in tourism demand. Indeed, the removal of visas as a sign of goodwill between Russian and Turkish governments in 2010 has increased the number of tourists coming to both countries. The place of Russian tourists in the tourism of Turkey, one of the important tourism destinations of the world, is significant (See table 2).

Table 2 Number of Russian Tourists and Tourism Receipts

\begin{tabular}{|l|c|c|c|c|c|}
\hline & $\mathbf{2 0 1 4}$ & $\mathbf{2 0 1 5}$ & $\mathbf{2 0 1 6}$ & $\mathbf{2 0 1 7}$ & $\mathbf{2 0 1 8}$ \\
\hline Number of Arriving Tourists to Turkey & 36.837 .900 & 36.240 .000 & 25.352 .213 & 32.410 .034 & 39.488 .401 \\
\hline Total Tourism Receipts (Thousand \$) & 34.305 .904 & 31.460 .000 & 22.107 .440 & 26.283 .656 & 29.512 .926 \\
\hline Number of Russian Tourists & 4.479 .049 & 3.649 .003 & 866.256 & 4.715 .438 & 5.964 .613 \\
\hline Share of Russian Tourists (\%) & 12.0 & 16.5 & 3.4 & 14.5 & 15.10 \\
\hline Rate of Change Russian Tourists (\%) & 4.9 & -18.5 & -76.2 & +444.35 & +26.49 \\
\hline Russian Tourist Receipts (Thousand \$) & 3.471 .263 & 2.609 .037 & 548.340 & 2.159 .671 & 3.483 .334 \\
\hline
\end{tabular}

Source: MCT (2018),TUIK (2018), Tourism Statistics.

In 2014, with pre-crisis and international relations continuing as normal, a total of 36.8 million tourists came to Turkey, 4,479,049 of which were Russian tourists. In 2015, 36.2 million tourists came to Turkey, 3,649,003 of which were Russian tourists. The number of Russian tourists is due to the economic crisis in Russia. In the aftermath of 2014, the value of Russian Ruble, trapped between decreasing oil prices on the one hand and Western sanctions that increased its pressure on the economy on the other, decreased 50\% against US Dollars (www.bbc.com). Following the aircraft crisis and the subsequent sanctions from Russia, 25.352.213 tourists came to Turkey in 2016 and the number of Russian tourists decreased by-76\%, to the number of 866.256.

In 2017, with the effect of resolving the aircraft crisis between Russia and Turkey, the number of tourists coming from Russia reached 4,715,438 compared to the previous year, which resulted a big bang in the increase ratio (444.35\%). In 2018, the number of tourists coming from Russia was 5,964,613 and the rate of increase in the number of Russian tourists was 26,49\%. In 2017-2018, Russians got the lead for highest number of tourists visiting Turkey, changing the rankings in which the German citizens led for years. Data from the last three years show that the crisis is over in a short time of one year. Among the reasons for the crisis to be overcome in a short period of a year can be listed as bilateral meetings and dialogue process with the counterparts of the high-level statesmen such as the President, the prime minister, foreign minister, minister of culture and tourism, the chief of staff (Çulha, 2016). In addition, activities such as Turkey Festival, tourism forums, workshops, participation to tourism fairs, diplomacy and public relations were focused on by the Ministry of Culture and Tourism, TURSAB and tourism sector (MCT, 2018).

Table 3 Comparison of Top Countries with Highest Tourists Visiting Turkey

\begin{tabular}{|l|l|l|l|l|l|l|l|l|}
\hline \multirow{2}{*}{ Nationality } & \multicolumn{3}{|c|}{ Years } & \multicolumn{4}{c|}{ Nationality Share \% } \\
\cline { 2 - 9 } & $\mathbf{2 0 1 5 *}$ & $\mathbf{2 0 1 6}$ & $\mathbf{2 0 1 7}$ & $\mathbf{2 0 1 8}$ & $\mathbf{2 0 1 5} *$ & $\mathbf{2 0 1 6}$ & $\mathbf{2 0 1 7}$ & $\mathbf{2 0 1 8}$ \\
\hline Russia & 3.649 .003 & 866.256 & 4.715 .438 & 5.964 .613 & 10.07 & 3.42 & 14.55 & 15.10 \\
\hline Germany & 5.580 .792 & 3.890 .074 & 3.584 .653 & 4.512 .360 & 14.25 & 15.34 & 11.06 & 11.06 \\
\hline Britain & 2.512 .139 & 1.711 .481 & 1.658 .715 & 2.254 .871 & 6.93 & 6.75 & 5.12 & 5.71 \\
\hline Georgia & 1.911 .832 & 2.206 .266 & 2.438 .730 & 2.069 .392 & 5.27 & 8.70 & 7.52 & 5.24 \\
\hline Bulgaria & 1.693 .591 & 1.690 .766 & 1.852 .867 & 2.386 .885 & 5.03 & 6.67 & 5.72 & 6.04 \\
\hline OTHER & 20.892 .643 & 14.987 .370 & 18.159 .631 & 22.300 .280 & 57.65 & 59.12 & 56.03 & 56.47 \\
\hline TOTAL & $\mathbf{3 6 . 2 4 0 . 0 0 0}$ & $\mathbf{2 5 . 3 5 2 . 2 1 3}$ & $\mathbf{3 2 . 4 1 0 . 0 3 4}$ & $\mathbf{3 9 . 4 8 8 . 4 0 1}$ & $\mathbf{1 0 0 . 0}$ & $\mathbf{1 0 0 . 0}$ & $\mathbf{1 0 0 . 0}$ & $\mathbf{1 0 0 . 0}$ \\
\hline
\end{tabular}

Source: TURSAB (2018); TUROB (2017). Statistics. 
Looking at the nationalities of the most visited tourists in 2015, the first three places belonged to Germany with $14.25 \%$, Russian Federation with $10.17 \%$ and England with $7.06 \%$. A serious decline took place in the number of foreign tourists coming to Turkey in 2016 and proportionately significant fluctuations have occurred. In the countries sending tourists to 2016, the number of foreign tourists coming from Georgia increased by $15.40 \%$ and serious decreases are observed in the remaining countries, however, the highest foreign tourist decrease is observed to be from Russian Federation, with a ratio of $76.26 \%$. It is obvious that the factor underlying such a decrease for the Russian Federation is the aircraft crisis. Another striking finding is the high decrease in the number and proportion of foreign tourists from European countries (31.87\% in the UK - 30.30\% in Germany). The reason for the loss of tourists from the German and UK market outside the Russian market in 2016 was the suicide attacks of the terrorist organizations such as PKK and ISIS, the terrorist attacks in Sultan Ahmet Square and Atatürk Airport, and the coup attempt on July 15th (Köşker, 2016).

In 2017, the number of tourists coming from Russia after the crisis increased dramatically, while it is observed that the number of European-based tourists and the decrease in their rates (5\% in the UK - 7.9\% in Germany) continued. According to the data of 2018, there has been a serious increase in the foreign tourist count coming from both Russia and the European countries such as Germany and England in terms of the proportional and numeric distribution of foreign tourists coming to Turkey based on their nationalities. The proportional increase of Russian tourists visiting Turkey in 2018 was realized as $20.94 \%$ compared to the previous year. It is observed that there is a $20.56 \%$ increase in the number of tourists coming from Germany and the proportion increase of tourists coming from the UK is $26.44 \%$.

Factors influencing the choice of destinations in the literature include geographic characteristics of the destination, infrastructure and superstructure status, transportation facilities, historical and cultural attractions, natural beauties, regional architecture, service quality and recreational activities (Davras \& Uslu, 2019). Other matters in destination selection include the distance to destination, tourist typologies, the buying behavior of tourists, not only the price factor and political factors, but also the climate, subculture, family, social classes, age, occupation, income situation and lifestyle (Kotler et al., 2013).

Table 4 Preferred Destinations by Russian Tourists

\begin{tabular}{|l|l|l|l|c|c|c|}
\hline \multirow{2}{*}{ Countries } & \multicolumn{3}{|c|}{ Years } & \multicolumn{3}{c|}{ Market Share \% } \\
\cline { 2 - 7 } & $\mathbf{2 0 1 5}$ & $\mathbf{2 0 1 6}$ & $\mathbf{2 0 1 7}$ & $\mathbf{2 0 1 5}$ & $\mathbf{2 0 1 6}$ & $\mathbf{2 0 1 7}$ \\
\hline Finland & 3.066 .658 & 2.894 .394 & 3.333 .000 & 14.6 & 14.5 & 12.42 \\
\hline China & 1.284324 & 1676214 & 2.003 .000 & 6.1 & 8.4 & 7.46 \\
\hline Estonia & 1.476 .915 & 1.511 .413 & 1.728 .000 & 7.0 & 7.5 & 6.43 \\
\hline Poland & 1.321 .767 & 1.103 .532 & 1.230 .000 & 6.3 & 5.5 & 4.58 \\
\hline Germany & 1.111 .448 & 1.057 .388 & 1.229 .000 & 5.3 & 5.3 & 4.57 \\
\hline Thailand & 675.089 & 866.597 & 1.094 .000 & 3.2 & 4.3 & 4.07 \\
\hline Cyprus & 550.327 & 812.741 & 869.000 & 2.6 & 4.0 & 3.24 \\
\hline Turkey & 3.649 .003 & 866.256 & 4.715 .438 & 17.4 & 4.3 & 17.57 \\
\hline Spain & 692.996 & 789.769 & 929.000 & 3.3 & 3.9 & 3.46 \\
\hline Greece & 633.585 & 782.476 & 856.000 & 3.0 & 3.9 & 3.18 \\
\hline Other countries & 5.459 .370 & 8.582 .348 & 10.853 .562 & 26.1 & 43.0 & 40.02 \\
\hline TOTAL & $\mathbf{2 0 . 9 2 1 . 4 8 2}$ & $\mathbf{1 9 . 9 4 3 . 0 4 8}$ & $\mathbf{2 6 . 8 4 0 . 0 0 0}$ & $\mathbf{1 0 0 . 0}$ & $\mathbf{1 0 0 . 0}$ & $\mathbf{1 0 0 . 0}$ \\
\hline
\end{tabular}

Source: TURSAB, 2018.

Referring to Table 4, Turkey is the first destination preferred by the Russians with a ratio of $17.4 \%$ and a tourist count of 3.649.003, followed by Finland with a ratio 
of $14.6 \%$ and a tourist count of 3.066.658 in the second place and Estonia with a ratio of $7.0 \%$ and a tourist count of 1.476 .915 in the third place. This is followed by Poland with $6.3 \%$ and China with $6.1 \%$. In 2016, this number and ratio of tourists decreased by $4.3 \%$ to 866.256 with the aircraft crisis between Turkey and Russia. With the resolution of the crisis, Turkey once again became the highest number of visited destination with a ratio of $17.57 \%$ and 4.715 .438 tourists in 2017 . It is observed that first destination that comes to mind of Russians for holiday is Turkey. The Russians prefer hot destinations as holiday destinations and also carry out touristic visits to the neighboring countries (Finland, Estonia, China, Germany etc.). Moreover, it is observed via this table that tourists prefer different destinations during the crisis periods. While 5.5 million Russian tourists preferred other countries in 2015, 8.5 million tourists preferred them in 2016. Around 3 million tourists who did not come to Turkey because of the crisis shifted to other countries.

\section{Conclusion and Suggestions}

In international relations, where conflicts, wars, migrations, human rights violations and extremist movements are increasing, the establishment of political balances has become very difficult. Balanced relations between the states will enable overcoming this difficult situation. However, interstate relations can be disrupted due to other countries as exemplified in the aircraft crisis between Turkey and Russia. The relations came to a point of halting with the Turkish Army Forces taking down the waraircraft of the Russian Federation Air Forces, which was situated in Syria due to the civil war, on 24.11.2015 due to border violation against Turkey.

In this research, the effects of international relations on tourism demand are assessed on the aircraft crisis between Turkey and Russia. In 2016, when the aircraft crisis occurred, a tourist loss ratio of $76 \%$ was experienced. In addition to the Russian market, tourist losses were experienced in Germany and the UK market in 2016 due to PKK, ISIS and FETO terrorist incidents. As a result of bilateral negotiations carried out the post-crisis statesmen, the activities conducted by Culture and Tourism Ministry with the cooperation of TURSAB and tourism sector, Turkey has weathered the crisis in a short period of 1 year. After the crisis, the number of tourists coming from Russia reached 4,715,438 compared to the previous year, which resulted a big bang in the increase ratio (444.35\%). In 2018, the number of tourists coming from Russia was $5,964,613$ and the rate of increase in the number of Russian tourists was $26,49 \%$.

As a response to Russia following an increasingly harsh and non-compromising policy against Turkey after the crisis (Demir, 2016), Turkey chose the way of diplomatic solutions and discussion, pointing out the damage that such a crisis could bring to both countries, especially to Turkey (Özçetin \& Baybars-Hawks, 2018: 46). The meeting of Minister of Foreign Affairs Mevlüt Çavuşoğlu and Sergey Lavrov at AGIT summit on 03.12.2015, President Erdoğan sending an apology letter to Putin for taking down the Russian aircraft on 27.06.2016, Prime Minister Binali Y1ldırım going to Moskov with the invitation of his Russian counterpart, Dmitriy Medvedev on 06.12.2016, the meeting between Putin and Turkish President Recep Tayyip Erdoğan in Moskov on 10.03.2017 (Çulha, 2016) helped the crisis to end in a short period of time and the relations to become normalized. Hence, the number of Russian tourists and the revenue increased beyond the pre-crisis period in 2017 and 2018.

The aircraft crisis between Russia and Turkey was difficult for Turkish tourism and led to significant losses in tourist count and tourism revenues. These losses indicate 
that the international relations with Russia, which is the second country with most tourists sent to Turkey, is effective on tourism demand.

The fact that Russian tourists choose other countries instead of Turkey during the crisis (see table 4) indicates that the economic factors affecting tourism demands such as income, price, transportation, exchange rate, distance, accommodation, supply capacity and promotion activities and socio-psychological factors such as fashion, pleasures and habits, rest and relaxation, leisure time, gender, age, family structure, occupation, cultural and educational level did not affect the tourism demand. However, it is exhibited that international relations under political environment within the external factors affected the tourism demand during the aircraft crisis between Russia-Turkey.

Researches have been found in the literature scan indicating that crises affect the tourism demand. Can et al. (2018) concluded that political crises between two countries caused a decrease in trade volumes of countries. Köşker (2017) exhibits that terrorist attacks and political crises caused great economic losses for Turkish tourism in 2016. These results are also supported with relevant studies in the literature studies, in that economic crises affect the tourism demand by Ayaz (2016), that terrorism events affect the tourism demand by Enders and Sandler (1991) and Masinde et al. (2016), that the epidemics affect the tourism demand by Coles (2003), that the crises affect tourism by Ongun (2005) and Vanneste et al. (2017) and that politic crises tourism and tourism demand by Yenişehirlioğlu et al., (2016) and Bayramov \& Abdullayev (2018).

A similar crisis process to Turkey-Russia aircraft crisis also occurred between Turkey and Israel. The period of tension and crisis between Turkey and Israel started with the "One Minute" statement that occurred in Davos on January 30, 2009 (Özdağ, 2011: 21). 558.183 Israeli tourists came to Turkey in 2008, while this number decreased to 311.582 in 2009 after the crisis (TUIK, 2008). On May 31, 2010, after Israel's attack on MV Mavi Marmara, Turkish-Israeli relations have entered into a severe crisis (Özdağ, 2011: 21). The same year, the number of Israeli tourists visiting Turkey has dropped to 109.559 (TURSAB, 2018). The relations between the two countries started to be normalized in 2013 when Israel declared a formal apology to the state, paid compensation to the families of the victims and lifted the embargo imposed on Gaza (Hasanov, 2014). With the normalization process, the number of Israeli tourists visiting Turkey increased every year and has reached 443,000 tourists in 2018 (TUIK, 2018; TURSAB, 2018).

Listed among the between the leading countries in the world with historical richness and natural beauties, Turkey stands out with important destinations having strong appeal. Due to developments in the world tourism and new trends, leading countries in tourism need to design new touristic products, moving the tourism away from the name of the country to the destination in order to strengthen the tourism (Davras \& Uslu, 2019). This will provide ease and mobility in dealing with the crises that may occur. In addition, utilizing the geographical advantages as opposed to limited markets such as Europe and Russia, alternative markets such as Arabia, China and India should be addressed. In order to overcome the crises with least damage, the countries should be able to market the destinations well and pay attention to the factors that affect the choice of destination in order to focus the tourists on the destination name rather than the country name. Another crisis-coping method is to turn to domestic tourists in the domestic market.

The fact that the trade between Russia and Turkey is carried out with Turkish Lira and Ruble instead of dollars will eliminate the exchange rate losses, this will reflect to the tourism demand in a positive manner, increasing the purchasing power of Russian tourists. 
The biggest limitation of the research is the fact that only the effects of the aircraft crisis between Turkey and Russia on tourism demand have been examined; incoming tourist counts from several other countries (for instance, Israel etc.) may be compared. The findings of the research and the interpretations thereof are based on secondary data. The opinions of Russian tourists may be obtained and added to the results of the research.

We can see the suggestion of good international relations between countries and the political influence on consumer behavior in tourism based on flights of tourist exchanges. For the researches planned to be carried out in the future, taking the opinions of Russian tourists will be able to explain the crises between Turkey and Russia in a better manner. Crisis strategies can be considered on a micro scale based on destinations such as Istanbul, Antalya, Muğla, Aydın and Cappadocia instead of considering them in a macro scale. Comparison of the crises arising between different countries such as Turkey and Russia Aircraft crisis can be made. The study is expected to shed a light on the tourism sector for possible crises that may arise in Turkey.

\section{References}

1. Albeni, M., \& Ongun, U. (2005). The significans of Antalya's tourism in Turkish tourism and the effects of crisis on tourism in Antalya, Journal Of SDU Economics and Administrative Sciences Faculty, 10(2), 93-112.

2. Altunışık, R., Coşkun, R., Bayraktaroğlu, S., \& Yıldırım, E. (2005). Research Methods in Social Sciences (SPSS Applied), 4th Edition, Sakarya; Sakarya Publishing.

3. Alvarez, L. S, Diaz A. M., \& Casielles R. V. (2007). Relationship marketing and information and communication technologies: analysis of retail travel agencies, Journal of Travel Research, 4(5), 453-463.

4. Ayaz, N. (2016). An analysis on the impact of economic crises over tourism sector. Electronic Journal of Social Sciences, 15(59), 1360-1371.

5. Aydemir, B. \& Bal, K. (2018). Tourism as a Foreign Policy Tool: The Case of Ghana, Journal of Turkish Tourism Research, 2(1), 71-84.

6. Aymankuy, Y. Ş. (2001). Turizm Sektöründe Kriz Yönetimi, Balıkesir Üniversitesi Sosyal Bilimler Dergisi, 6(2), 100-123.

7. Bahar, O., \& Kozak, M. (2013). Tourism Economics. Eskisehir: Anadolu University Press.

8. Bayramov, E., \& Abdullayev, A. (2018). Effects of political conflict and terrorism on tourism: How crisis has challenged Turkey's tourism development. B. Udvari \& E. Voszka (eds.). In Challenges in National and International Economic Policies.University of Szeged, 160-175.

9. BBC (2014). https://www.bbc.com/turkce/ekonomi/2014/12/141215_rusya_mb, (accessed in December 25, 2018).

10. Beirman, D. (2003). Restoring Tourism Destination in Crisis: A Strategic Management Approach. Crows Nest, Australia: Allen \& Unwin,

11. Can, E., Özmutlu, S. Y., \& Aykaç, C. (2018). An econometric analysis on Turkey-Russia Aircraft Crisis. International Social Research Congress, 26-27 April 2018 (p.14), Istanbul/Turkey.

12. Coles, T. (2003). A local reading of a global disaster. Journal of Travel \& Tourism Marketing, 15(3), 173-197. 
13. Çulha, E. (2016). Chronology of Turkish-Russian Relations (1991-2017). Marmara University Journal of Turkology, 3(2), 287-298.

14. Davras, Ö., \& Uslu, A. (2019). Effect on destination satisfaction of the destination selection factors: a research on English tourists in Fethiye. MANAS Journal of Social Studies, 8(1/1), 691-708.

15. Davras, M. G., \& Aktel, M. (2018). The reflections of 2015-2016 crisis on tourism in Turkey.

16. Suleyman Demirel University Visionary Journal, 9(21), 27-38.

17. Demir, A. F. (2016). Reflections and effects of the Syrian crisis on TurkishRussian relations. Marmara University Journal of Turkology, 3(2), 139-151.

18. Dinçer, Ö. (1992). Strategic Management and Business Policy, Istanbul: Timaj Printing House.

19. Eker, S. (2014). Syria Crisis and Reflections on Jordan. Journal Of Çankırı Karatekin University Economics And Administrative Sciences Faculty, 4(2), 2134.

20. Enders, W., \& Sandler, T. (1991). Causality between transnational terrorism and tourism: The case of Spain. Studies in Conflict \& Terrorism, 14(1), 49-58.

21. Erşen, E. (2016). Normalization of Turkish-Russian relations under the shadow of the Syrian problem. Marmara University Journal of Turkology, 3(2), 153171.

22. Fletcher, J., Fyall, A., Gilbert, D., \& Wanhill, S. (2012). Tourism: Principles and Practice (6th Edition). Harlow: Pearson Education.

23. Frances, B. (2010). Tourism Reassessed: Blight or Blessing, ButterworthHeinemann, UK:London.

24. Gajdošik, T., Hrubvoca, G., Šramek, J., Tittelbachova, Š. (2015). Approaches to the economization of cultural heritage in context of destination management in the Czech Republic. Journal of Competitiveness, 7 (1), 22-34.

25. Glancy, M. (2011). Political Economy of Tourism: A Critical Perspective, in: Global commodity chains and tourism, Editor: Jan Mosedale, Routledge Publishing,USA: New York.

26. Hasanov, E. (2014). After the Mavi Marmara Turkey-İsraeli Relations. ORMER Perspective Series, 6, 1-8.

27. Henderson, J. C. (2007). Tourism Crisis: Causes, Consequences and Management. U.K.: Routledge.

28. Henderson C. J. (2016). Tourism Crisis: Causes, Consequences and Management. New York, USA: Routledge.

29. İmambeyli, V. (2015). Air crisis and Turkey-Russia Relations. Journal of Perspective, 119, 1-7.

30. Ključnikov, A., Krajčík, V., Vincúrová, Z. (2018). International Sharing Economy: the Case of AirBnB in the Czech Republic. Economics and Sociology, 11(2), 126-137.

31. Konrad, G. (2017). The SAGE International Encyclopedia of Travel and Tourism, in: Internaional Relations and tourism, (Encyclopedia Articel 655), editor: Linda L. Lowry, Sage Puplishing, Inc. USA: Colifornia.

32. Kotler, P., Bowen, J., \& James, M. (2003). Marketing for Hospitality and Tourism (Third Edition). New Jersey, USA: Prentice Hall.

33. Kozak, M, Kozak, M., \& Kozak, N. (2015). General Tourism Principles and Concepts (18th Edition). Ankara: Detay Publishing.

34. Kozak, M. (2015). Bilimsel Araştırma: Tasarım, Yazım ve Yayım Teknikleri, Ankara: Detay Publishing. 
35. Köşker, H. (2017). A research on the effects of the crisis to tourism sector: the example of Turkey in the 2016 year. Journal of Academic Review, 62, 216-233

36. Loganathan, N., Streimikiene, D., Mursitama, T. N., Shahbaz, M., Mardani, A. (2018). How Real Oil Prices and Domestic Financial Instabilities are Good for GCC Countries Tourism Demand in Malaysia? Economics and Sociology, 11(2), 112- 125.

37. Luecke, R. (2009). Kriz Yönetimi, Çev., Önder Sarıkaya, 3. Baskı, Harvard Business Press, Türkiye İş Bankası Kültür Yayınları, İstanbul.

38. Luštický, M., \& Kincl, T. (2012). Tourism Destination Benchmarking: Evaluation and Selection of the Benchmarking Partners. Journal of Competitiveness, 4(1), 99- 116.

39. Masinde, B. K., Buigut. S., \& Mungatu, J. K. (2016). Modelling the temporal effect of terrorism on tourism in Kenya. International Journal of Economics and Finance, 8(12), 10-20.

40. Matthews, H. G. (1978). International Tourism: A Political and Social Analysis. Cambridge, Schenkman Publishing Company.

41. MCT (2018). Ministry of Culture and Tourism (MCT) Directorate General for Promotion, Russia Market Report, http://www.tanitma.gov.tr/Eklenti/59089, rusyapazarraporu2018, (accessed in February 01, 2019).

42. Okumuş, F., \& Karamustafa, K. (2005). Impact of an economic crisis, Annals of Tourism Research, 32(49), 942-961.

43. Olal1, H. (1981). Tourism Courses. İzmir: İstiklal Press.

44. Özdağ, Ü. (2011). How real is the crisis between Ankara and Tel Aviv? Journal of 21st Century, 5, 21-30.

45. Özçetin, B. \& Baybars-Hawks, B. (2018). Framing the Russian aircraft crisis: news discourse in Turkey's polarized media environment. Journal of International Affairs, 57, 33-47.

46. Paksoy, A. Ç. (1999). Public Relations Practices in Turkey, Istanbul: Route Publications.

47. Pizam, A. (1999). A comprehensive approach to classifying acts of crime and violence at tourism destinations. Journal of Travel Research, 38(2), 5-12.

48. Proença, S. A., \& Soukiazis, E. (2005). Demand for tourism in Portugal: A panel data approach. http://www4.fe.uc.pt/ceue/working_papers/isaraelias29.pdf, (accessed in February 02, 2019).

49. Reilly, A. (1987). Are organizations ready for crisis? A managerial scorecard. Columbia Journal of World Business, 22, 79-88.

50. Seçilmiş, C., Kılıç, İ., \& Doğantekin, A. (2017). The impact of the political crisis on tourism and a crisis management model proposal. The First International Congress On Future Of Tourism: Innovation, Entrepreneurship and Sustainability, 28-30 September 2017 (p.498), Mersin/Turkey.

51. Simone, P. (2007). Preface: the tsunami of 26 December 2005, PATA's initial responses. E. Laws, B. Prideaux \& K. Chon (eds.). In Crisis Management in Tourism. CABI, U.K.

52. Sönmez, S. F., Apostolopoulos Y., \& Tarlow P. (1999). Tourism in crisis: managing the effects of terrorism. Journal of Travel Research, 38(1), 13-18.

53. Şahin, E., Konak, F., \& Karaca, S. S. (2017). Impact of "aircraft crisis" between Turkey and Russia on Borsa Istanbul food, beverage and tourism indexes. Business and Economics Research Journal, 8(3), 473-485. 
54. Tengilimoğlu, D., \& Öztürk, Y. (2004). Public Relations in Business Management. Ankara: Seçkin Publishing.

55. Tunç, A., \& Saç, F. (1998). General Tourism Development-Future. Ankara: Detay Publishing.

56. TUROB (2017). Statistics. Hotel Association of Turkey, http://www.turob.com/tr/istatistikler, (accessed in December 17, 2018).

57. TURSAB (2018). Statistics. Association of Turkish Travel Agencies, https://www.tursab.org.tr/istatistikler/milliyetlerine-gore-gelen-yabanci*, (accessed in January 27, 2019).

58. TUIK (2018). Tourism Statistics. Turkish Statistical Institute, www.tuik.gov.tr, (accessed in January 30, 2019).

59. Tüz, M. (2002). Crisis Instant Business Management. Istanbul: Alfa Publications.

60. UNWTO (2018). United Nations World Tourism Organization Tourism Highlights, https://www.e-unwto.org/doi/pdf/10.18111/97892844198, (accessed in February 02, 2019).

61. Vanneste, D., Tudorache, P., Teodoroiu, F., \& Steenberghen, T. (2017). The impact of the 2016 terrorist attacks in Brussels on tourism, journals.openedition.org/be.p.1-26, (accessed in February 01, 2019).

62. Yenişehirlioğlu, E., Salha, H., \& Şahin, S. (2016). Research aimed at the effect of political crises on tourism demand: Russia's changing visage and its effects on Turkish tourism. Balkan and Near Eastern Journal of Social Sciences, 02(03), 74-83.

63. Yeşiltaş, M., Öztürk, İ., \& F. Türkmen, F. (2008). An assessment in the perspective of possible solutions for terror effects on tourism sector. Journal of Social Sciences, 10(1), 175-189.

64. Yıldırım, A., \& Şimşek, H. (2008). Qualitative Research Methods in Social Sciences (7th Edition). Ankara: Seçkin Publishing.

\title{
Brief description of Author/Authors:
}

\author{
Abdullah USLU \\ Assistant professor \\ Department of tourism management \\ Manavgat Faculty of Tourism \\ Akdeniz University, Turkey \\ Emek Mah. Piyade Er Fikret Karamusaoğlu Cd. No:156, 07600, \\ Manavgat/Antalya/Turkey \\ +902427427025 \\ auslu@akdeniz.edu.tr
}

Abdullah is an assistant professor in the Faculty of Manavgat Tourism in Akdeniz

University. His main research areas are tourist behaviour, destination management and service quality.

\section{Bayram Akay \\ Asisstant Professor \\ Department of travel management \\ School of Tourism and Hotel Management}


Burdur Mehmet Akif Ersoy University, Turkey

İstiklal Yerleşkesi, 15030 Burdur/Turkey.

+902482134400

bakay@mehmetakif.edu.tr

Bayram is an assistant professor and head of travel management in the School of Tourism and Hotel Management at Mehmet Akif Ersoy University. His research interests include strategic management in tourism, education in tourism and destination management. 